\title{
プラスチック溶着製品の界面構造と機械強度の相関
}

\author{
姫 野 貴 則

\section{Relationship between Interfacial Structure and Mechanical Strength of Thermoplastic Welded Products}

Takanori HIMENO (Department of Phenomenon Analysis, NISSAN ARC, LTD., 1, Natsushima-cho, Yokosuka, Kanagawa 237-0061, Japan) himeno@nissan-arc.co.jp

Molding and welding conditions have a significant influence on the mechanical properties of the thermoplastic welding products. In this paper, we described our investigation of the relationship between the interfacial structure and the mechanical strength of them. Especially, we focused on the weld line of polyamide and the welded interface of poly (phenylene sulfide). Using the N-ARC method (the original photo based observation method) and imaging infrared, the traces of the molten polymer flow and the higher-order structure were analyzed. These results showed that the weld line and the welded interface became the fatal defects for their mechanical properties.

(Received on January 31, 2017)

Key Words : Interface, Welding, Bonding, Strength, Morphology, Polymer Analysis

\section{1. は じ め に}

自動車産業では, 自動車の軽量化や低燃費化, 乗員と歩 行者の安全を狙いとして, 自動車部品の樹脂化が精力的に 進められている。また, 100 種以上の自動車部品でプラス チックの溶着・接着といった二次加工技術が採用されてい る.プラスチックの溶着・接着品は, 接合強度や高い密封 性の他, 長期信頼性も求められ, 接合状態が製品の性能・ 機能へ与える影響が大きい.

自動車で採用されるエンジニアリングプラスチックで最 も需要が高いポリアミド（PA）樹脂は, インテークマニ ホールド, ラジエータタンク, エンジンカバー等の機構部 品に多く使用されている. 近年, ポリフェニレンサルファ イド（PPS）樹脂の注目度が高く, 耐熱性・耐薬品性・難 燃性・成形性・高強度等の特性を活かし, エコカーのエン ジンとモーター関連部品に適用され, 自動車一台当たりに 対するPPS樹脂の使用量は飛躍的に増加している.

ウエルドラインを有する成形品や溶着部品の強度は, 内 部に形成する界面の影響を受けることが多いため, 高性能
かつ長寿命な “ものづくり”では, 材料選定や成形・加工 によって界面を制御することが重要となる. 図 1 に材料分

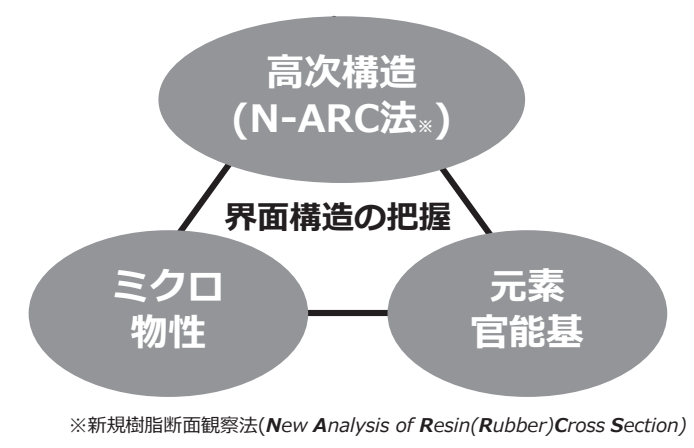

図1 材料分析視点における界面構造の把握方法

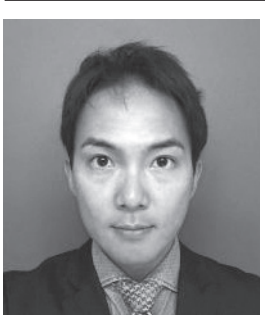

姫野 貴則 ; (侏日産アーク 現象解析部 ( ⿳亠 厂 237-0061 神奈川県横須賀市夏島町 1 番地). 2003 年, 大阪府立大学総合科学部物質科学科 (現理学部物理科学科) 卒業. 2004 年, (株)日産 アーク入社，現在に至る。専門は，顕微鏡観 察によるモルフォロジー解析. 
析視点における界面構造の把握手法を示す。現象解析手法 として，接合界面で生じる官能基の同定や元素分布測定を 用いた分析事例は多く発表されている ${ }^{1,2)}$ が，それらに加 えて, 高次構造観察とミクロ物性評価を併用することによ り，現象を多面的に把握できると考えられる.

本特集では，プラスチック成形品の強度や溶着強度を発 現する因子の抽出方法, 一次成形 - 二次加工条件の最適化 を行うための方法として，我々独自の樹脂・ゴム断面観察 法 (N-ARC 法: New Analysis of Resin (Rubber) Cross-Section Method ${ }^{3)}$ ) を用いた高次構造観察を中心と した複合解析事例を紹介する.

\section{2. 材料組織学に基づく成形品の現象解析}

結晶性高分子材料において, 高次構造の一つである球晶 の構造・サイズ・分布・数・密度・最近接粒子間距離など と物性には密接な関係がある。例えば，粗大化した球晶を 多く含む成形品は脆くなる（硬さ・弾性率が上昇する）場 合があるが，これは球晶が大きくなる程，内部欠陥が増加 するためと考えられる，また，球晶が大きくなると，球晶 により可視光線が散乱するため不透明になる。繊維強化樹 脂の一次成形（溶着前の成形）で観察される形態は，スキ ン層 (冷却層), 球晶, トランスクリスタル, 分子配向, 強化繊維の分散・配向状態, ポリマーアロイの相分離構造 などが挙げられるが, これらの構造は, 成形時の樹脂温 度・金型温度・射出速度・保圧等の成形条件により様々变 化する。また，二次加工を代表する溶着を例に挙げると， 加熱により一次成形で形成した高次構造が溶融し, 再度固 化する過程において溶着界面に新たな高次構造を形成す る.この新たな構造は, 被着体へ与える熱量や沈み込み量 （ストローク量）等の条件により様々変化する.

このように，材料の物性発現に直結する構造因子を明ら かにするためには，形態観察による組織解析が出発点と考 える.ちなみにN-ARC 法観察は, 光学顕微鏡によりマク ロ〜ミクロの広範囲で成形品内部の形態を鮮明に観察する ことができる. 本手法は, 材料組織学視点で一次成形の良・ 不良品の差異や，二次加工による界面形成状態の差異を判 断することができることから，N-ARC 法は成形条件と接 合条件を最適化する手法となる。

\section{3. 仮説検証型現象解析のための「N-ARC 法」組織解析}

図 2 に $-\mathrm{ARC}$ 法観察の手順と, PA66 およびNR/SBR 製 ギアの断面観察事例を示す。超精密研磨面を調製すること により，成形時に溶融した樹脂およびゴムが流動しながら 固化した痕跡を鮮明に可視化できる。また，NR/SBR製ギ アには脆弱なウエルドライン近傍に亀裂が発生しているこ とが分かる。

図3にN-ARC法による現象解析の流れを示す。材料分
析の視点から, 成形不良や溶着不良による強度低下を現象 解析するためには，不具合現象に至るまでの背景を整理し た上で，仮説を立てることが重要となる。ささに仮説は複 数であることが望ましく，それぞれの仮説を検証するため に, N-ARC 法による高次構造観察を主軸として多岐にわ たる分析を併用する。これらの分析結果に基づき, 仮説を 絞り込む.

さらに，材料組織学視点により不具合現象に至る因子 (金型温度や樹脂温度等) を抽出し, 成形条件への改善提 案を行う。改善した成形品に不具合が生じなければ良い が, 再発する場合は別の仮説を立て, 再度調査を進めるこ とで新たな改善方法を検討する。このように，N-ARC 法 による組織解析を切り口とした現象解析方法は, 成形加工 条件へ迅速かつ的確なフィードバックを可能とする.

\section{4. 金型温度差による高次構造変化とミクロ物性との相関}

\section{1 試験片の情報と引張強度試験結果}

金型温度条件のみ変更した, PA66樹脂（非強化） ASTM ダンベル試験片の引張試験結果と N-ARC 法観察事 例を紹介する。試験片は射出成形で作製し, 試験片中央で ウエルドラインを形成させるため, ゲートは試験片両端二 点とした，表1に主な成形条件と引張試験結果を示す。成 形時の樹脂温度は $280^{\circ} \mathrm{C}$, 金型温度はそれぞれ $40{ }^{\circ} \mathrm{C}$ と 110 ${ }^{\circ} \mathrm{C}$ とした。また，引張試験前に温度 $23{ }^{\circ} \mathrm{C}$ ，相対湿度 $50 \%$ の室内で 48 時間, 状態調節を行った。両試料とも破断位
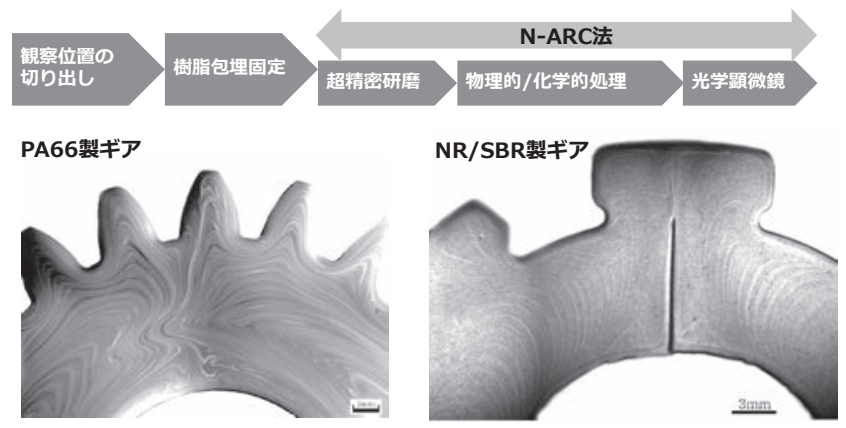

図2 N-ARC 法断面観察の手順と，PA66 およびNR/SBR製ギアの断 面観察事例

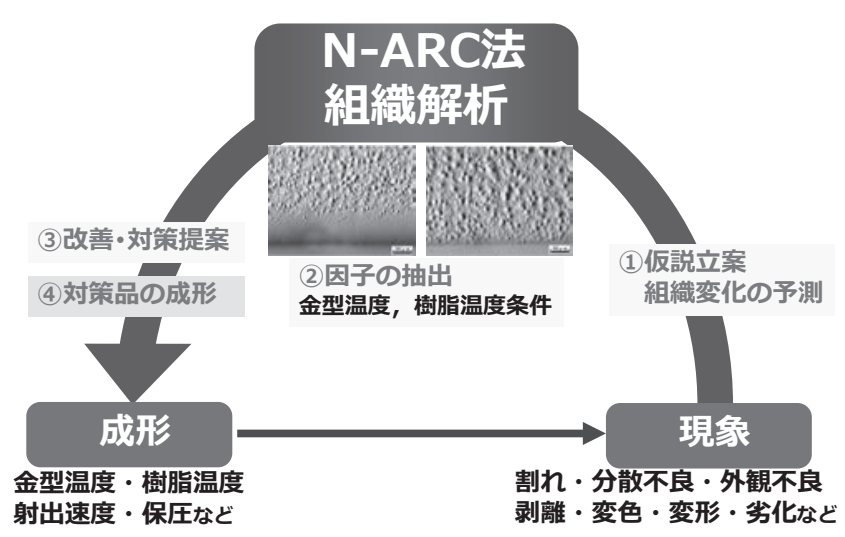

図３－ARC法を活用した仮説検証型“現象解析”の手順 
置はウエルド部近傍で, 引張強さは $86 \mathrm{~N} / \mathrm{mm}^{2}$ で有意差は 認められなかったが, 金型温度 $40{ }^{\circ} \mathrm{C}$ 試験片は破断伸びが 約 $5 \%$ 高い值を示した。この理由については，金型温度 40 ${ }^{\circ} \mathrm{C}$ 試験片の表層は結晶化度が低いためと推察される.

$\mathrm{N}-\mathrm{ARC}$ 法観察結果から, マクロ的視点による考察と, ミクロ的視点による考察を行うことができる。眓 4 に $\mathrm{N}-\mathrm{ARC}$ 法による断面マクロ観察結果を示す。両試料のウ エルドラインの形状が大きく異なり，金型温度 $110{ }^{\circ} \mathrm{C}$ 試験 片は，ウエルドラインが深い入り組み構造を形成してい た。この形態は，溶融樹脂が合流する際の粘性に起因して いると考えられる。すなわち，溶融樹脂は金型により冷却 されながら充填される。金型温度 $40{ }^{\circ} \mathrm{C}$ 試験片のウエルド 領域では，粘性が高い溶融樹脂が合流するため，入り組み 形態が浅く形成される。これに対して，金型温度 $110{ }^{\circ} \mathrm{C}$ 試 験片では，溶融樹脂温度が低下しにくく，ウエルド領域の 粘性が低いため，ウエルドラインが入り組んだものと考え られる。

図5に, N-ARC法による断面ミクロ観察結果を示す. 試験片の表層には，金型と接触して形成された冷却層や球 晶が明瞭に可視化される。冷却層の厚さは，金型温度 40 ${ }^{\circ} \mathrm{C}$ 試験片が約 $70 \mu \mathrm{m}$, 金型温度 $110{ }^{\circ} \mathrm{C}$ 試験片は約 $7 \mu \mathrm{m}$ で あった。 また，金型温度 $40{ }^{\circ} \mathrm{C}$ 試験片は，冷却層から深さ 方向へ球晶が次第に大きくなる傾向を示したが，金型温度 $110{ }^{\circ} \mathrm{C}$ 試験片は表層に粗大化した球晶が形成していた。

一方, 試験片中央では, 金型温度 $40{ }^{\circ} \mathrm{C}$ 試験片は大小の 球晶が混在するのに対して，金型温度 $110{ }^{\circ} \mathrm{C}$ 試験片は粗大 化した球晶で占められていた。 このことは，金型温度 110 ${ }^{\circ} \mathrm{C}$ 試験片は球晶の成長が促進されたことを示唆する。従っ て，製品設計時には，溶融樹脂が金型と接触して熱量を失 うことも念頭に入れておく必要がある。

\section{2 ミクロ物性分布評価結果}

図6に,インデンテーション法による微小領域における

表1ダンベル試験片の主な成形条件と引張試験結果

\begin{tabular}{c|c|c|c}
\hline 金型温度 & 樹脂温度 & $\begin{array}{c}\text { 引張強さ } \\
\left(\mathrm{N} / \mathrm{mm}^{2}\right)\end{array}$ & 破断伸び \\
\hline $40{ }^{\circ} \mathrm{C}$ & \multirow{2}{*}{$280{ }^{\circ} \mathrm{C}$} & 85.4 & $13.2 \%$ \\
\cline { 3 - 4 } & & 86.0 & $8.5 \%$ \\
\hline $110{ }^{\circ} \mathrm{C}$ &
\end{tabular}

硬さ測定結果を示す。測定位置は，両試料とも，試験片表 面から約 $20 \mu \mathrm{m}$ 深さの位置（表層と記す）と試験片中央 （中央と記す）に固定し， N-ARC法観察した研磨面を測定 試料とした。測定結果から，両試料ともに試験片表層（冷 却層）の硬さは中央より低いことが分かる，また，試験片 表層の硬さを金型温度間で比較すると，金型温度 $40^{\circ} \mathrm{C}$ 試 験片は，表層の硬さが約 $10 \%$ 低い。また同領域において， $\mathrm{N}-\mathrm{ARC}$ 法観察で球晶が可視化されていないことから，金 型温度 $40{ }^{\circ} \mathrm{C}$ 試験片表層は, 金型温度が低いことによって 溶融樹脂が急冷固化し，すなわち結晶化度が低下するた め，硬さが低下したと考えられる．さらに，金型温度 40 ${ }^{\circ} \mathrm{C}$ 試験片の中央の硬さは，有意差はないものの $110{ }^{\circ} \mathrm{C}$ 試験 片よりやや低い傾向を示した。これは大小の球晶が混在し た N-ARC 法観察結果と傾向が合致する。

以上から，N-ARC法による高次構造観察結果と, ミク ロ物性とは相関があると考えられる。

\section{3 まとめ}

本試験片の引張試験では, 両試料とも破断位置はウエル ドライン近傍で, 引張強さは $86 \mathrm{~N} / \mathrm{mm}^{2}$ で有意差がなく, 金型温度 $40{ }^{\circ} \mathrm{C}$ 試験片は破断伸びが約 $5 \%$ 高い值を示した。 両試料の引張試験後の破面観察から, 破壊起点は試験片中 央で, 表層が最終破断部となるカップ・アンド・コーン型
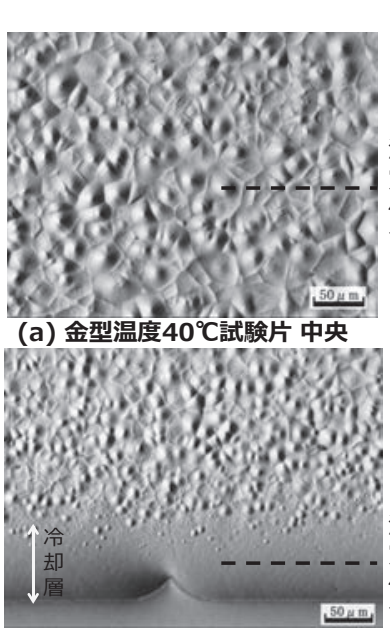

(c) 金型温度 $40^{\circ} \mathrm{C}$ 試験片 表層
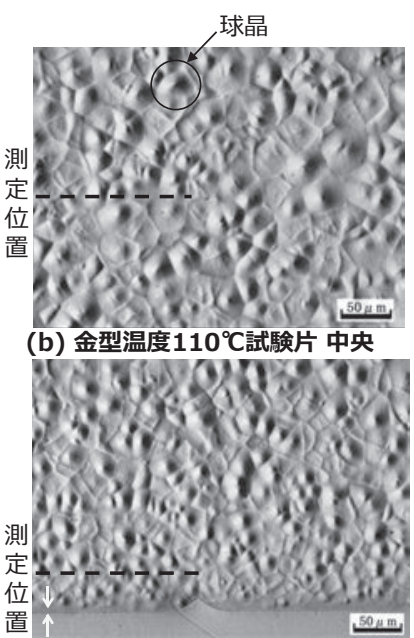

(d) 金型温度 $110^{\circ} \mathrm{C}$ 試験片 表層

図5 金型温度条件のみ異なるPA66製ダンベル試験片の N-ARC法 断面ミクロ観察結果
図4 金型温度条件のみ異なるPA66製ダンベル試験片の N-ARC 法断面マクロ観 察結果
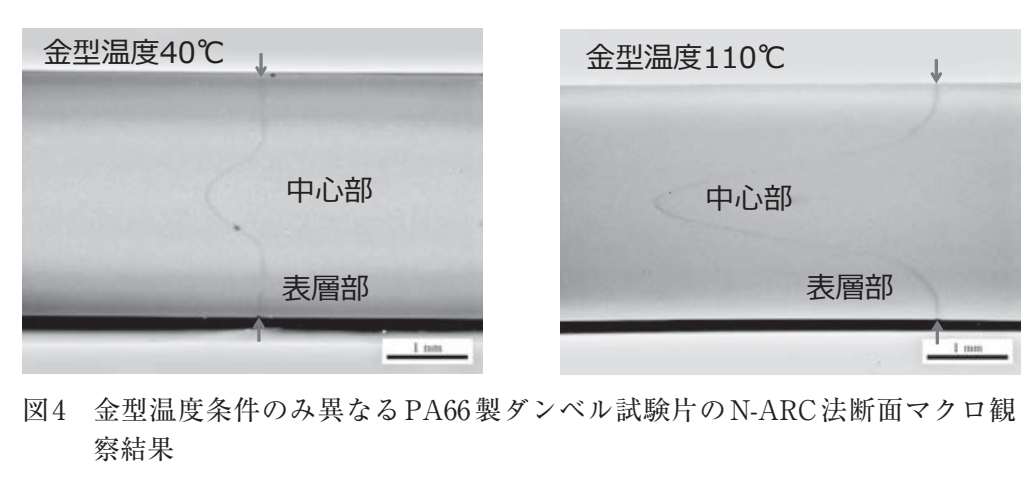
と判断した。両試料とも，破壊起点となった試験片中央の 硬さに有意差がないことから, 引張強さは同程度となった と考えられる。また，金型温度 $40{ }^{\circ} \mathrm{C}$ 試験片は，最終破断 部となる表層の硬さが低いことから破断伸びが高い傾向を 示したと考えられる。

以上から，成形時におけるウエルド強度対策は，ウエル ド領域において溶融樹脂温度の低下を防ぐことが望まし く，対策例として，樹脂温度・金型温度の設定值を上げる ことや，温度が低下した溶融樹脂を排出するオーバーフロ ータブを設置することなどが挙げられる，また，その他の 事例として，金属インサート成形品のウエルド強度が低下 する場合も要因は類似している。予備加熱を実施していな いインサート金属によって，溶融樹脂温度は急激に低下し ながら合流する。ささらに，インサート金属により急冷固化 した領域には, 残留歪みが生じやすく, ウエルド強度が著 しく低下することに注意が必要である.

\section{5. プラスチックの溶着強度と界面構造の相関}

表2に主なプラスチックの熱溶着工法を示す. 溶着とは, 熱板, 超音波, 赤外線などを用いて複数の被着体の表面を 溶融させた後, 接触・加圧させながら冷却・固化の過程を 経て接合する技術である。加熱により，被着体表面の高次 構造は溶融するが, 比較的速く固化するため, 溶着部は分 子鎖の絡み合いや結晶化が進行しないと共に，分子鎖の配 向性が緩和されない場合が多い。また，加熱によって発生 するガス（ボイド）や熱劣化した樹脂が溶着界面に残存す
ることは強度低下を招くため，このようなガスに関しては 溶融状態で被着体を加圧・流動させ, 溶着部外へバリとし て溶着界面から排出することが望ましい" ${ }^{4)}$.

図7にポリアセタール（POM）樹脂同士の振動溶着品 の N-ARC 法観察事例を用いて, 材料組織学に基づいた溶 着強度発現因子を示す。

まず，溶着界面にボイドや未溶着部が内在することで, 溶着不良領域（11) が発生し, 溶着幅（2)）が低下するこ とが挙げられる。また, 溶着強度試験を実施すると, 破壊 起点は溶着中央部もしくは溶着端部となる，溶着中央部が 破壊起点となる要因は, 溶着界面に生じる新たな高次構造 に応力が集中するためと考えられる．N-ARC法観察によ り, 溶着部周辺に新たに形成する溶融層・流動固化層 - 再 結晶層等の高次構造を可視化し, 各層厚さを判定すること ができる，光学顕微鏡観察の結果から, POM樹脂の溶着 界面には，球晶が観察されなかったことから，母材と比較 して結晶性が低下した領域が局在化し, 力学的に不連続な 界面構造（3）を形成していると考えられる。また溶着端 部が破壊起点となる要因は，両被着体から排出するバリ同 士の界面, バリの形状やバリに内在するボイド (4)）等で あると考えられる。

溶着強度発現メカニズムを解明するためには, 溶着条件 によって様々変化する上記(1)〜 (4)と, 溶着強度との相関を 考察する必要がある。図8に溶着強度解析の手順を示す.

溶着強度試験品の破面解析による破壊起点の特定, 強度 試験前後の断面観察, 強度試験前の結晶性・ミクロ物性分

表2プラスチックの主な熱溶着工法

\begin{tabular}{|c|c|c|c|c|c|c|}
\hline \multirow{2}{*}{ 項目 } & \multicolumn{2}{|c|}{ 外部加熱 } & \multicolumn{3}{|c|}{ 自己発熱 } & \multirow{2}{*}{$\begin{array}{c}\text { 型内溶着 } \\
\text { DSI成形 }\end{array}$} \\
\hline & 熱板溶着 & 赤外線溶着 & 超音波溶着 & 振動溶着 & レーザー溶着 & \\
\hline $\begin{array}{l}\text { 適合形状 } \\
\text { (制限有無) }\end{array}$ & $\begin{array}{c}\text { 複雑な } 3 \text { 次元 } \\
\text { 形状以外 }\end{array}$ & $\begin{array}{c}\text { 複雑な } 3 \text { 次元 } \\
\text { 形状以外 }\end{array}$ & 小さい部品 & $\begin{array}{c}\text { 複雑な } 3 \text { 次元 } \\
\text { 形状以外 } \\
\text { (振動方向に } \\
\text { よる制限有) }\end{array}$ & $\begin{array}{c}\text { 比較的肉厚の } \\
\text { 薄い部品 }\end{array}$ & $\begin{array}{c}\text { 金型から離型 } \\
\text { できること }\end{array}$ \\
\hline 適合材料 & $\begin{array}{c}\text { 熱可塑性樹脂 } \\
\text { 一部不可 }\end{array}$ & $\begin{array}{c}\text { 熱可塑性樹脂 } \\
\text { 一部不可 }\end{array}$ & $\begin{array}{c}\text { 熱可塑性樹脂 } \\
\text { 全般 }\end{array}$ & $\begin{array}{c}\text { 熱可塑性樹脂 } \\
\text { 全般 }\end{array}$ & $\begin{array}{c}\text { 透過材と吸収 } \\
\text { 材の組合せ }\end{array}$ & $\begin{array}{l}\text { 熱可塑性 } \\
\text { 樹脂全般 }\end{array}$ \\
\hline 接合部外観 & 一部はみ出し & 良好 & 一部はみ出し & 一部はみ出し & 良好 & 良好 \\
\hline 部品への影響 & 熱 & なし & 振動 & 振動 & なし & - \\
\hline
\end{tabular}

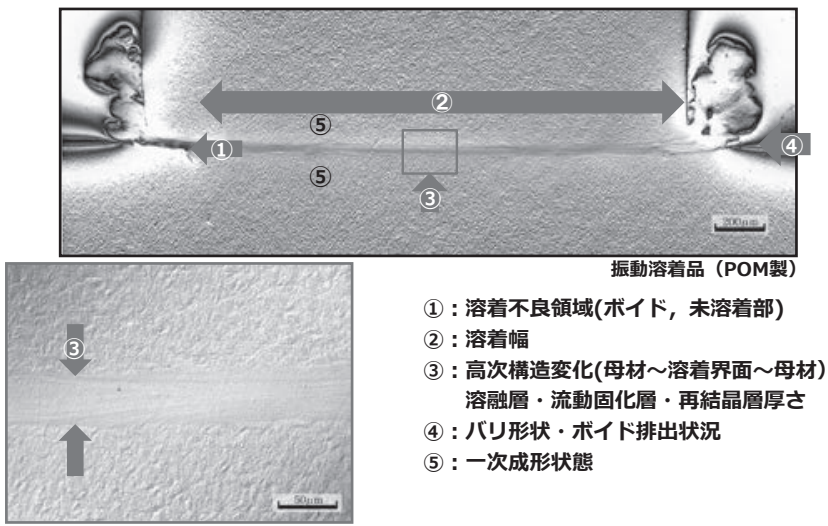

図7 材料組織学に基づく溶着強度発現因子

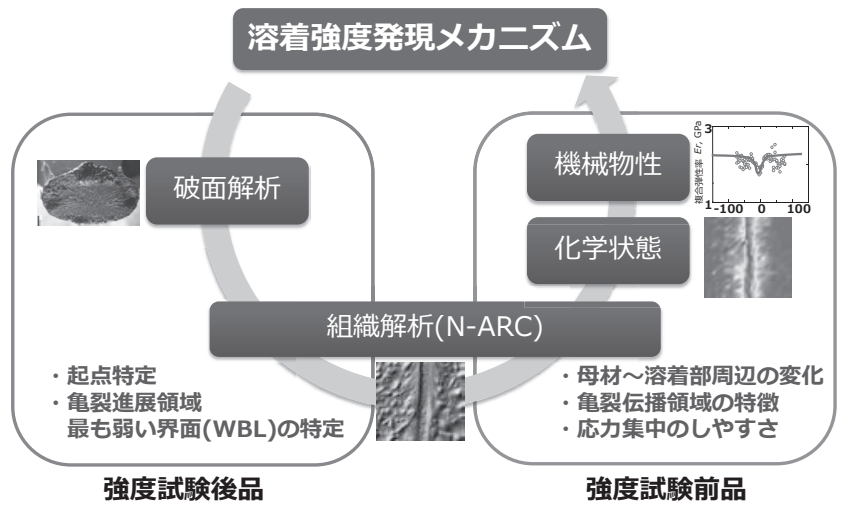

図 8 溶着強度解析の手順 
布評価を行うことが望ましい。ささに，同一条件で成形し たテストピース間の溶着では考慮する必要はないが，異な る実成形品同士の溶着の場合は，被着体の一次成形状態 (5) にも注意が必要である。

\section{PPS 樹脂の溶着強度と界面構造との相関 ${ }^{5)}$}

\section{1 試験片の情報と引張強度試験結果}

赤外線溶着品の溶着強度解析事例を紹介する. 赤外線溶 着の模式図と溶着条件を図 9 に示す。ガラス繊維 $40 \%$ 強化 PPS樹脂（直鎖型）を用いて, ISO3167多目的試験片（幅 $20 \mathrm{~mm} \times$ 全長 $150 \mathrm{~mm} \times$ 厚さ $4 \mathrm{~mm}$ ）を片側一点ゲートに て射出成形し, 試験片中央部を切断したものを赤外線溶着 した。溶着時の押し付け圧力を $1.8 \mathrm{Bar}$ ，溶着時間を 5 秒 で固定し，異なる溶着強度が得られるように，赤外線照射 時間を $8 \sim 12$ 秒と変化させて溶着を行った。沈み込み深 さをそれぞれ $0.85 \mathrm{~mm}, 0.15 \mathrm{~mm}$ と変化させて赤外線溶着 を行ったところ，溶着強度はそれぞれ $58 \mathrm{MPa}$ と $32 \mathrm{MPa}$ であり，それぞれ試料 A，Bとした。

\section{2 強度試験後品の調査}

図 10 に赤外線溶着後の試料外観と強度試験後の破面を 実体顕微鏡で観察した結果およびN-ARC 法断面観察結果 を示すＮ-ARC法観察は，破断した試験片を突き合わせ， 破壊起点部を観察位置とした。

試料 A は沈み込み量が多いため, 溶着部の溶融樹脂が バリとして排出し，溶融面積が広くなっている，破壊起点
は試験片中央, 亀裂は放射状かつ連続的に進展した延性破 壊であった。これに対して, 試料Bは沈み込み量が少ない ため，排出バリ量は僅かとなっている，破壊起点は試験片 中央端部に形成した半円状の平滑領域, 亀裂は不連続的に 進展した脆性破壊であった. N-ARC法観察から, 両試料 の破壊位置は溶着部に形成した黒色の筋状痕跡間であっ た. 沈み込み量が多い試料 Aは, 破断部周辺のガラス繊 維がハの字に変化していた。試料 A は, ガラス繊維の配 向が変化するほど加圧したことにより，溶着部の絡み合い 効果が向上したと考えられる.さらにガラス繊維の配向形 態がハの字になり, 纎維の粗密が生じた部位を破壊起点と していた.

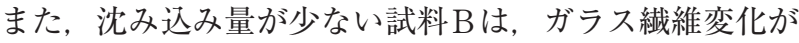
認められなかった。これは，赤外線溶着は溶融した樹脂を 加圧するため, 溶融樹脂の流動に伴いガラス繊維が配向す ると考えられる。

一方, 試料 Bは, 溶融樹脂に対して加圧力が不足し, 溶 着部の絡み合い効果が低いと考えられ, 不十分な溶着領域 が破壊起点となっていた。

\section{3 強度試験前品の調査}

図 11 に強度試験前の断面マクロ・ミクロ観察結果を示 す.

試料 $\mathrm{A}$ では, 溶着界面にボイドや未溶着部による溶着 不良領域は認められず，排出バリが厚く, 図7の(2)で示し た溶着幅を広げていた。破壊起点相当部にも欠陥は認めら

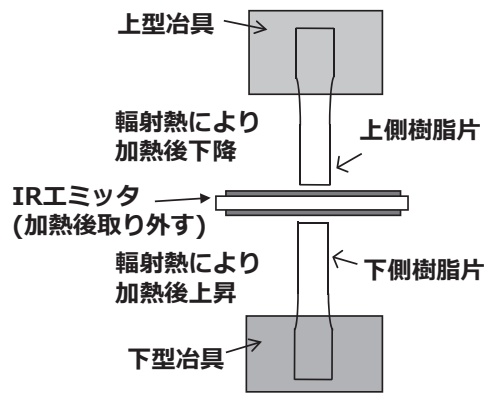

接触時 溶着後

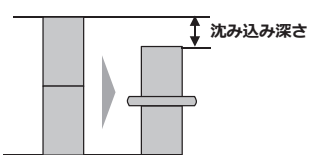

\begin{tabular}{c|c|c|c|c|c}
\hline 試料 & $\begin{array}{c}\text { 圧力 } \\
(\mathrm{Bar})\end{array}$ & $\begin{array}{c}\text { 溶着時間 } \\
(\mathrm{sec})\end{array}$ & $\begin{array}{c}\text { IR } \\
\text { 照射時間 } \\
(\mathrm{sec})\end{array}$ & $\begin{array}{c}\text { 沈み込み深さ } \\
(\mathrm{mm})\end{array}$ & $\begin{array}{c}\text { 引張強度 } \\
(\mathrm{MPa})\end{array}$ \\
\cline { 1 - 4 } $\mathrm{A}$ & \multirow{2}{*}{1.8} & 5 & 12 & 0.85 & 58 \\
\cline { 1 - 1 } $\mathrm{B}$ & & 5 & 8 & 0.15 & 32 \\
\hline
\end{tabular}

図9 赤外線溶着（Contoured Infrared Technology）の模式図および沈み込み深さのイメージと溶着条件

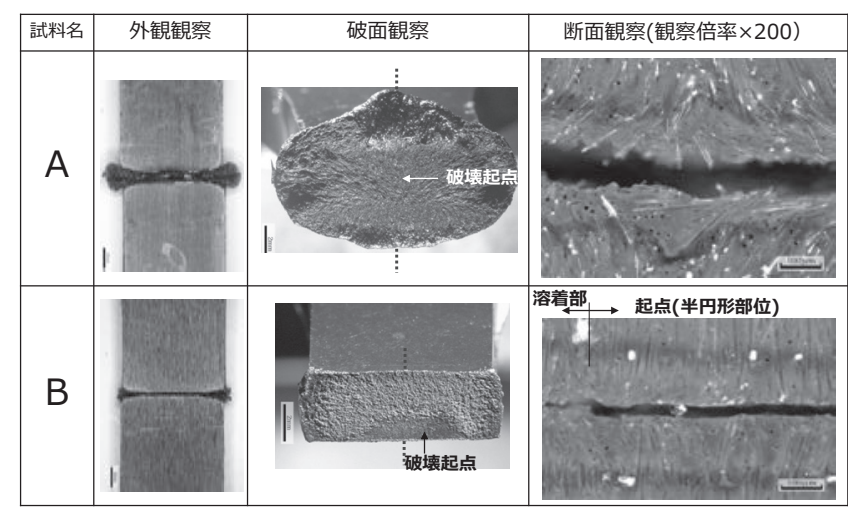

図 10 溶着試料外観と強度試験後の破面観察およびN-ARC 法断面ミ クロ観察結果

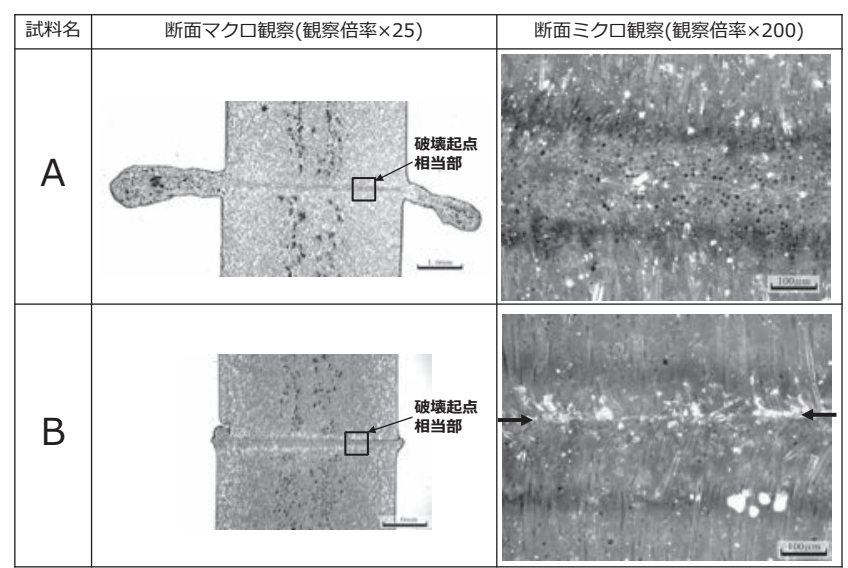

図 11 強度試験前のN-ARC 法断面マクロ・ミクロ観察結果 


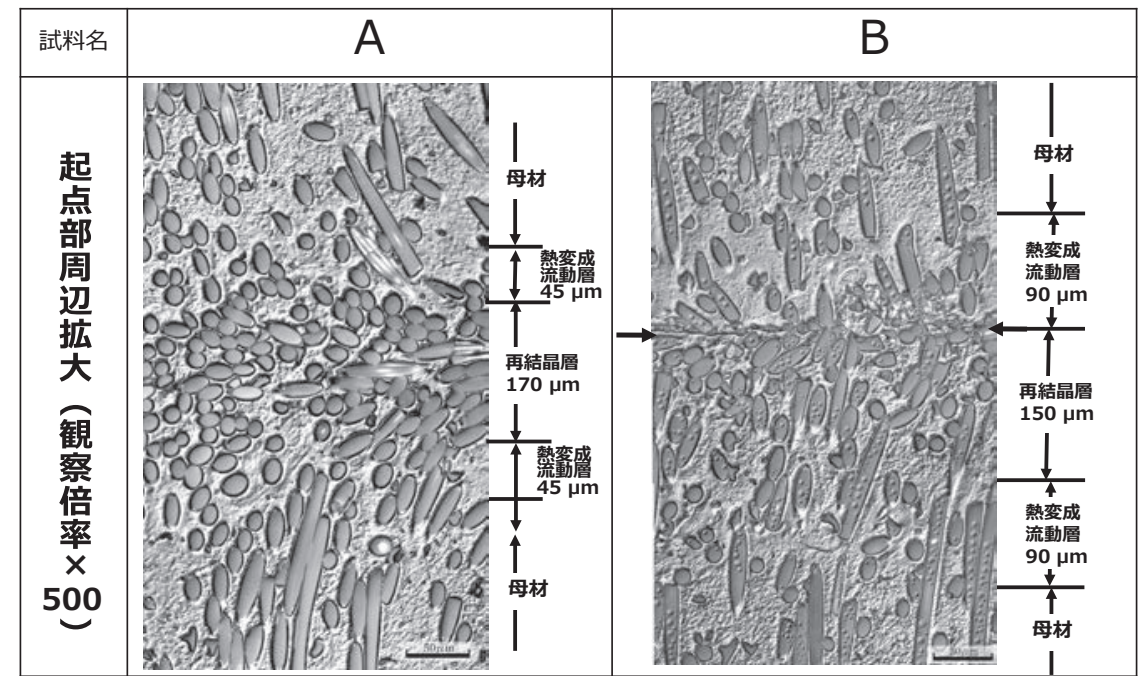

図 12 破壊起点相当部位の N-ARC 法断面ミクロ観察（強度試験前品調查）

れなかった。これに対して試料 Bは, 破壊起点相当部に明 瞭な筋状界面 (未溶着部) やボイドの発生などの溶着不良 領域を形成すると共に，溶着幅が狭くなっていた。

図 12 に破壊起点相当部位の N-ARC 法ミクロ観察結果を 示す. 一次成形したPPS樹脂の高次構造が変化する領域 から，両試料とも溶着部に三層構造を形成していると考え られる。詳細には溶着界面中央は，溶融樹脂が徐冷されて 形成したと考えられる再結晶層，その上下には溶融樹脂が 流動しながら固化したと考えられる熱変性・流動層, 溶着 界面や母材の粒状模様は球晶と考えられる.

試料 $\mathrm{B}$ の破壊起点相当部には, 再結晶層と熱変性・流動 層の間に明瞭な界面（矢印間）が存在し，前述未溶着部が 破壊起点となったと考えられる。また，三層の厚みが厚 く, 母材と熱変成流動層の高次構造変化が大きいため, 試 料Bの溶着界面は力学的に不連続であると考えられる。こ れらの形態は，沈み込み量が少なく，溶融樹脂に対して加 圧力が不足したため, 溶着界面は熱量が低下した樹脂で溶 着していると考えられる。.さらに試料 $\mathrm{A}$ は, 試料 $\mathrm{B}$ と比較 して三層の厚みが薄く，母材と熱変成流動層の高次構造変 化が小さいため, 溶着界面は傾斜構造を形成していると考 えられる，沈み込み量が多いことにより，溶融樹脂やボイ ドがバリとして排出したため, 試料 $\mathrm{A}$ の溶着界面は試料 $\mathrm{B}$ と比べて，溶着が顕著に改善されたと考えられる．

\section{7. おわりに}

$\mathrm{N}-\mathrm{ARC}$ 法とその他の分析法を併用することにより，プ ラスチック成形品の機械強度（マクロ物性）と高次構造と の相関を見出すことができる。これらの相関関係を把握す
ることは, 市場不具合要因の推定, 設計・開発や試作・量 産条件の最適化を行うための出発点となる.さらに, もの づくりの精度とスピードを向上するためには，迅速かつ的 確な判断が要求される。仮説に基づいて, 不具合現象を引 き起こす高次構造変化を予め予測し, 着目点を明確にして おくことが，現象を理解する近道となると考える．ものづ くりにおいて, 市場品質不具合の発生数を減らすために は，市場投入を見据えて後工程に課題を持ち越さず，可能 な限り上流工程で解決することが望ましいと考えられ, 組 織解析を切り口とした現象解析方法の活用が期待される.

\section{謝辞}

本調査にあたり PPS 溶着試験片作製にご協力頂きまし た宇佐美聡氏, 日下良太氏（日本エマソン株式会社 ブラ ンソン事業本部), 向井絵美氏, 宮原謙二氏, 加藤淳氏 （日産アーク）に深く感謝する。

\section{References}

1 ) Kato, A.: Nippon Gomu Kyokaishi, 79, 367 (2006)

2) Miyahara, K.: Material Stage, 7 (1), 30 (2007)

3 ) Kato, A.; Ishikawa, I.: Gouseijyushi, 44 (2), 56 (1998)

4) Miyahara, K:: Material Stage, 7 (1), 36 (2007)

5 ) Himeno, T.; Miyahara, K.; Mukai, E.: Seikei-Kakou Gakkai Nenjitaikai Yoshishu, 205 (2016)

\section{日本語表記引用文献}

1 ) 加藤淳：日本ゴム協会誌，79，367(2006)

2 ) 宮原謙二：月刊 MATERIAL STAGE， 7 (1)，30 (2007)

3 ）加藤淳, 石川伊千郎, 合成樹脂, 44 (2), 56（1998）

4) 宮原謙二：月刊 MATERIAL STAGE， 7 (1)，36 (2007)

5 ) 姫野貴則, 宮原謙二, 向井絵美 : プラスチック成形加工学会 年 次大会予稿集，205（2016） 